\title{
LAS PINTURAS ACROMÁTICAS DE ARTHUR HEMING (1870-1940)
}

\author{
MIR-FULLANA F ${ }^{1}$
}

Arthur Henry Howard Heming nació en París, pero no en Francia, sino en una pequeña y hermosa población con este topónimo en Ontario, Canadá. Tenía una especial predisposición para las artes y el atletismo y a los dieciséis años comenzó sus viajes por las zonas más salvajes de aquel inmenso país. Pronto envió los dibujos de sus expediciones que fueron publicados en diversas revistas americanas como el Harper's Weekly. Estudió arte en Toronto y

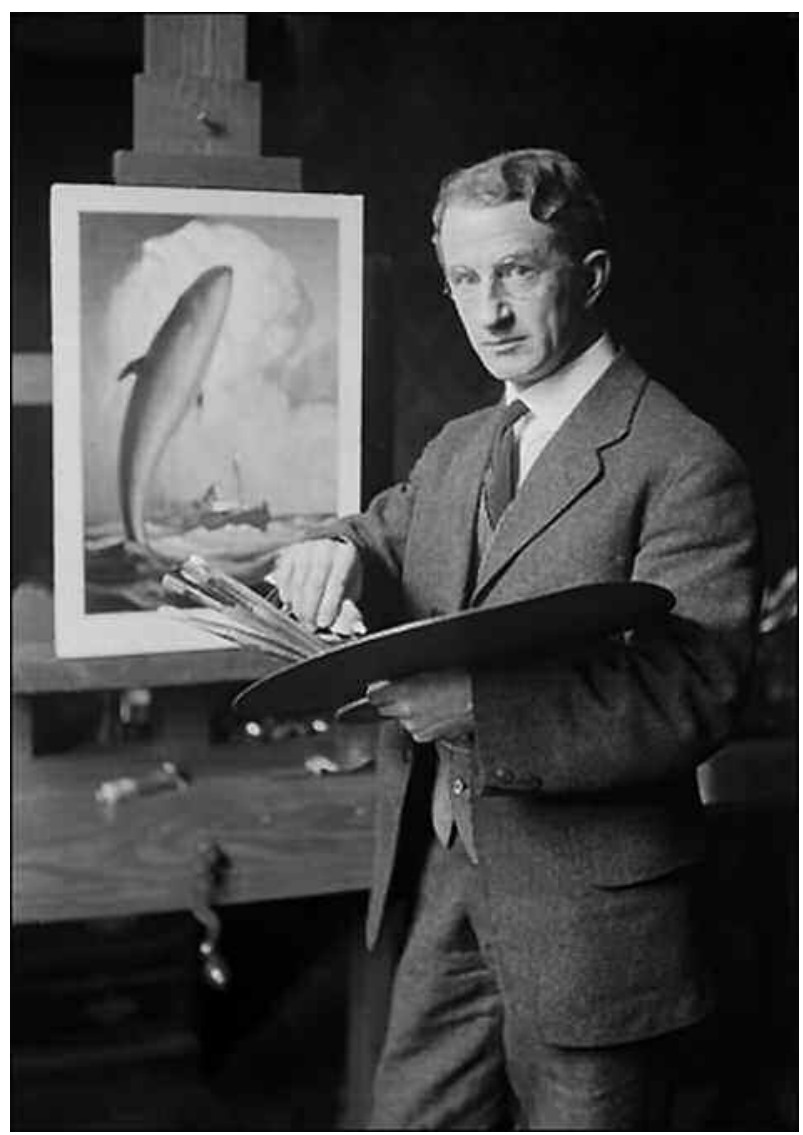

Arthur Heming, 1912. más tarde en Nueva York con Frank Vincent DuMond y en Londres con Frank Brangwyn.

La fama internacional de Heming, conocido como el cronista del Norte, la consiguió con sus descripciones de las tierras norteñas de Canadá publicadas en varios libros que incluyen dibujos y pinturas. Sus ilustraciones de la vida salvaje de la región, de sus tramperos y de los pueblos aborígenes fueron ampliamente divulgadas tanto en Esta-

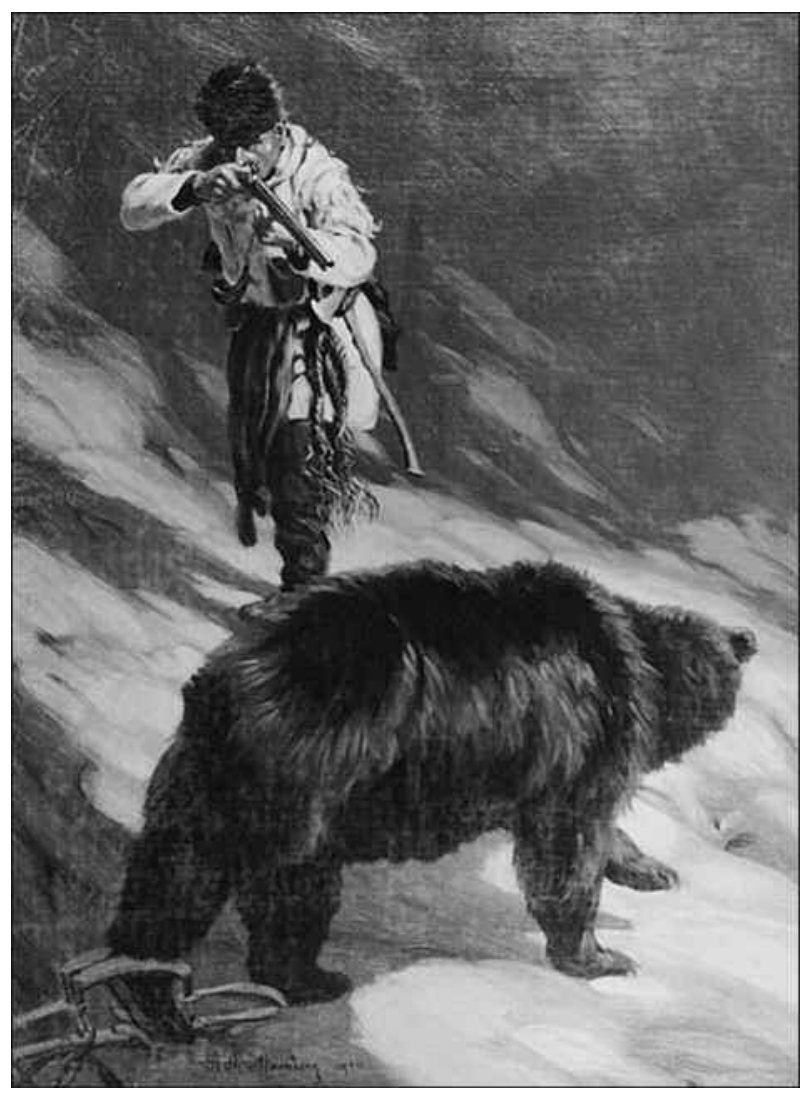

Heming, 1910. Cazador de osos. National Gallery of Canada.

\footnotetext{
1 Oftalmólogo.

E-mail: Fmir@mutuabalear.es
} 


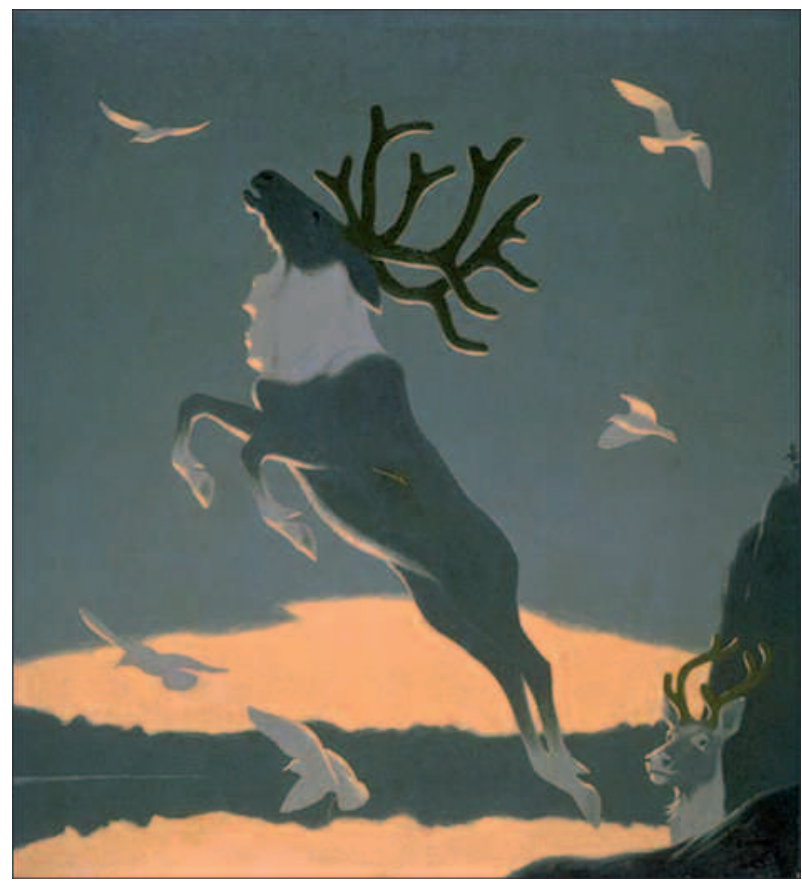

Heming, 1925. Caribú saltando.

dos Unidos como en Europa. También se editaron tres novelas sobre el tema que consiguieron un notable éxito internacional: Spirit Lake en 1907 (1), The Drama of the Forests (2) en 1921 y The Living Forest (3) en 1925. Pero tras su muerte, durante muchos años su figura como artista quedó en el olvido. La razón fundamental para ello, fue seguramente que el mundo del arte lo consideraba más un ilustrador que un verdadero pintor

A Heming le diagnosticaron en su adolescencia una ceguera parcial a los colores o discromatopsia, posiblemente un daltonismo. Por temor a utilizar erróneamente los colores, adoptó una postura radical y al mismo tiempo increíble: pintó y dibujó exclusivamente en blanco, negro y amarillo hasta 1930, año en que cumplía los sesenta años.

La curiosidad radica en que en aquel año se le notificó que en realidad no padecía ninguna altera-

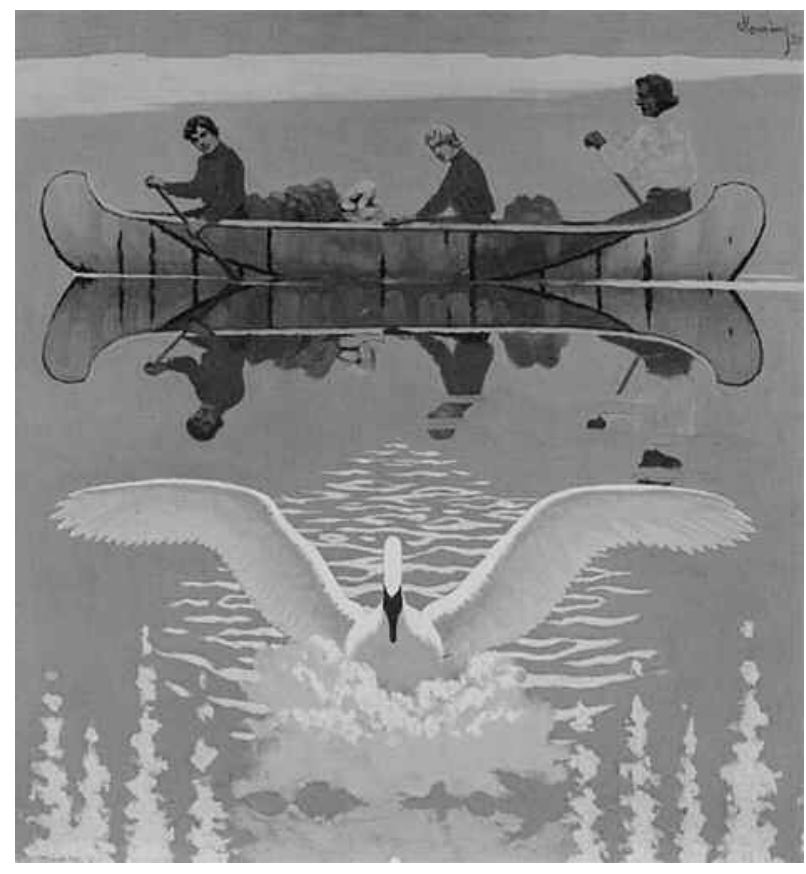

Heming, 1925. Cómo viajábamos.

ción en su visión cromática y desde entonces inició una etapa caracterizada por los colores vivos y brillantes de sus obras que no abandonó hasta su muerte diez años después.

A pesar de su última década de pinturas de gran riqueza cromática, en la gran mayoría de páginas de la red y en sus biografías se sigue afirmando que se trataba de un pintor con problemas en la visión de los colores y que por ello su obra fue monocromática.

\section{BIBLIOGRAFÍA}

1. Heming A. Spirit Lake. Toronto: Musson Book Co; 1923.

2. Heming A. The Drama of the Forests. Garden City: Doubleday; 1921.

3. Heming A. The Living Forest. Toronto: SB Hundí; 1925. 